\title{
Heavy Metal Accumulation in Maize (Zea mays L.) Grown on Chromated Copper Arsenate (CCA) Contaminated Soil Amended with Treated Composted Sewage Biosolid
}

\author{
C. K. Nakiguli ${ }^{*}$, B. Namakula ${ }^{1}$, J. Odda ${ }^{2}$, J. Wasswa ${ }^{3}$, E. Ntambi ${ }^{1}$ \\ ${ }^{1}$ Chemistry Department, Faculty of Science, Mbarara University of Science \& Technology, Mbarara, Uganda \\ ${ }^{2}$ International Health Sciences, Clarke International University, Kampala, Uganda \\ ${ }^{3}$ Chemistry Department, School of Physical Sciences, College of Natural Sciences, Makerere University, \\ Kampala, Uganda \\ Email: *carolkiwanuka@gmail.com, *cnakiguli@must.ac.ug
}

How to cite this paper: Nakiguli, C.K., Namakula, B., Odda, J., Wasswa, J. and Ntambi, E. (2018) Heavy Metal Accumulation in Maize (Zea mays L.) Grown on Chromated Copper Arsenate (CCA) Contaminated Soil Amended with Treated Composted Sewage Biosolid. Journal of Environmental Protection, 9, 1196-1204. https://doi.org/10.4236/jep.2018.911075

Received: July 14, 2018

Accepted: October 28, 2018

Published: October 31, 2018

Copyright $\odot 2018$ by authors and Scientific Research Publishing Inc. This work is licensed under the Creative Commons Attribution International License (CC BY 4.0).

http://creativecommons.org/licenses/by/4.0/

\section{(c) (i) Open Access}

\begin{abstract}
A pot experiment was conducted to investigate the heavy metal accumulation in maize (Zea mays L.) plant grown in chromated copper arsenate (CCA) soil amended with treated composted sewage biosolid. The initial concentrations of chromium, copper, arsenate in the CCA soil and sewage biosolid were determined by atomic absorption spectrophotometer. These were found to be, in CCA soil: $365.8 \pm 6.18,109.22 \pm 14.04,28.22 \pm 3.8$ and in sewage biosolid: $35 \pm 1.06,1.0 \pm 0.02,0 \mathrm{mg} \cdot \mathrm{kg}^{-1}$ respectively. The concentration of $\mathrm{Cr}, \mathrm{Cu}$ and As determined in both the roots and shoots generally decreased with increase in percentage amendment concentration and number of days (20 and 40 days after planting). At 20 days, the total metal concentration ranges in roots were As (5.54 $\pm 0.03-6.69 \pm 1.14), \mathrm{Cr}(9.59 \pm 0.02-13.22 \pm 0.03), \mathrm{Cu}(2.28 \pm 0.06$ $-4.53 \pm 0.37) \mathrm{mg} \cdot \mathrm{kg}^{-1}$ while at 40 days the values were As $(5.60 \pm 0.19-6.08 \pm$ $0.01), \mathrm{Cr}(9.47 \pm 0.04-10.95 \pm 0.09), \mathrm{Cu}(3.94 \pm 0.19-4.64 \pm 0.07) \mathrm{mg} \cdot \mathrm{kg}^{-1}$. For the shoot system, the concentrations of the metals at 20 days were As $(5.28 \pm 0.03-5.90 \pm 0.13), \mathrm{Cr}(9.30 \pm 0.05-10.07 \pm 0.06), \mathrm{Cu}(3.64 \pm 0.12-$ $4.72 \pm 0.15) \mathrm{mg} / \mathrm{kg}$ while at 40 days the values obtained were As (5.28 \pm 0.03 $5.9 \pm 0.13), \mathrm{Cr}(9.69 \pm 0.14-10.07 \pm 0.03), \mathrm{Cu}(2.94 \pm 0.72-4.53 \pm 0.03)$ $\mathrm{mg} \cdot \mathrm{kg}^{-1}$. The roots accumulated the three heavy metals more than the shoot system at all treatments used. Concentration of arsenic, chromium and copper in the plants decreased with increasing percentage amendments. The results suggest relatively low bioavailability of the three metals in CCA soil treated with high percentages of sewage biosolid as an amendment.
\end{abstract}




\section{Keywords}

Arsenic, Chromium Copper, Contaminated CCA Soil, Sewage Amendment

\section{Introduction}

The environment is under constant threat from man's activities due to expanding population, industrialization, urbanization, intensive agriculture and among others. These have led tremendous damage to the environment [1] as a result of deposition of heavy metal contaminated wastes on land. Heavy metals and their compounds are a threat to environment health and this has led to considerable concern because heavy metals are toxic, bio-accumulate and affect human life [2] [3] [4].

The pollution resulting from urban and industrial pollution has led to a gradual degradation of the natural environment. This phenomenon is serious and requires great efforts to correct the situation and prevent its proliferation. That is why the scientific knowledge of the contamination process is paramount. Although heavy metals are naturally present in the soil, geologic and anthropogenic activities increase the concentration of heavy metals to harmful levels to both plants and animals. Some of the activities include mining and smelting of metals, burning of fossil fuels, use of fertiliser and pesticides in agriculture, sewage sludge, production of batteries and other metal products and pole/timber treatment. Chromated copper arsenate (CCA) and creosote are the major chemicals used to treat timber. The former is widely used as a chemical preservative for pole treatment to improve quality and durability. It is composed of oxides of chromium $(35 \%-65 \%)$, copper $(16 \%-45 \%)$ and arsenic $(18 \%-20 \%)$. Copper and arsenic are the active ingredients used to preserve wood while chromium is used as a fixing agent that enables the fixing of the CCA compounds to wood. There are allowable limits for CCA that treated wood must retain and these depend on the wood product produced [5]. Chemical spill-over normally occurs during use of CCA to treat wood and also due to poor disposal of the effluents and solid waste to the environment. This eventually results in high levels of arsenic copper and chromium in the vicinity of an active wood treating industry. Studies have been done [6] [7] [8] [9] showing that soil in the vicinity of an active wood-treatment site has averagely high concentrations of arsenic, copper and chromium with potential to contaminate ecosystems especially water resources.

In Uganda, with its taxation policy (tax holiday), many small-scale industries have been set up mostly in urban and peri-urban areas, doing different activities and producing various products for the market. Among such industries include those dealing in producing poles for distributing electricity, fencing of land and timber for construction. These are scattered and treat poles with CCA and creosote but lack treatment facilities. Those which use CCA are many when com- 
pared to those using creosote. The CCA industries discharge effluents and solid wastes into swamps, water channels and on land with substantial levels of chromium, arsenic and copper. This practice stands a chance of contaminating the environment and poses a threat to the ecosystem. Thus, CCA contaminated soil was chosen for the study.

A number of methods have been used to remediate contaminated soil [5]. Most of them are expensive or do not completely remediate the soil and some may make the soil less productive [9]. The use of hyperaccumulating plants [9] to remediate or extract metals from soil has been found to have limitations of slow growth rates and yields of low biomass. These limitations coupled with the low movement and bioavailability of heavy metals in soil has led to the introduction and use of fast growing crops/plants (like maize) that generate high biomass and if these are used in combination with chemicals in biosolids added as amendments to soil, can alter the mobility and bioavailability of the heavy metals [10].

There vast amounts of sewage biosolid generated at different plants of National Water and Sewerage Corporation (NWSC) in the country that can be used in remediating contaminated soils, but currently are limited for use mainly in flower industry and laying courtyards. Biosolids are good candidates for improving soil properties, minimize soil degradation and have the ability to retain and/or minimize plant uptake of heavy metals. This is the reason why the sewage biosolid was chosen for this research and therefore, the study examined the effects sewage biosolid on accumulation of arsenic, copper and chromium in maize (Zea mays L.) in CCA contaminated soil. This would help to come up with a cost-effective remediation technology for soil contaminated with CCA particularly at a wood treatment sites.

\section{Materials and Methods}

\subsection{Description of the Study Site}

The CCA soil was collected from the wood factory premises located at Kitetika village (Figure 1), Nangabo sub-county, Wakiso District, seven miles along Gayaza road from the center of Kampala City. The factory is located on coordinates 0.4030814 and 32.585174 . The factory was established in the year 2000 and its main function is the production of treated of wood poles using CCA chemical.

\subsection{Sample Collection and Preparation}

Chromated copper arsenate soil used in this study was collected from Kitetika active wood factory site at a depth of $0-15 \mathrm{~cm}$ in the North Eastern part of Kampala City. Plastic spade was used to collect the samples and later the soil was spread on a clean polythene sheet in a shade. Stones and plant debris were removed; the soil was screened through a $2 \mathrm{~mm}$ stainless steel sieve and kept in a clean polythene bag at room temperature for further use. Composited sewage 


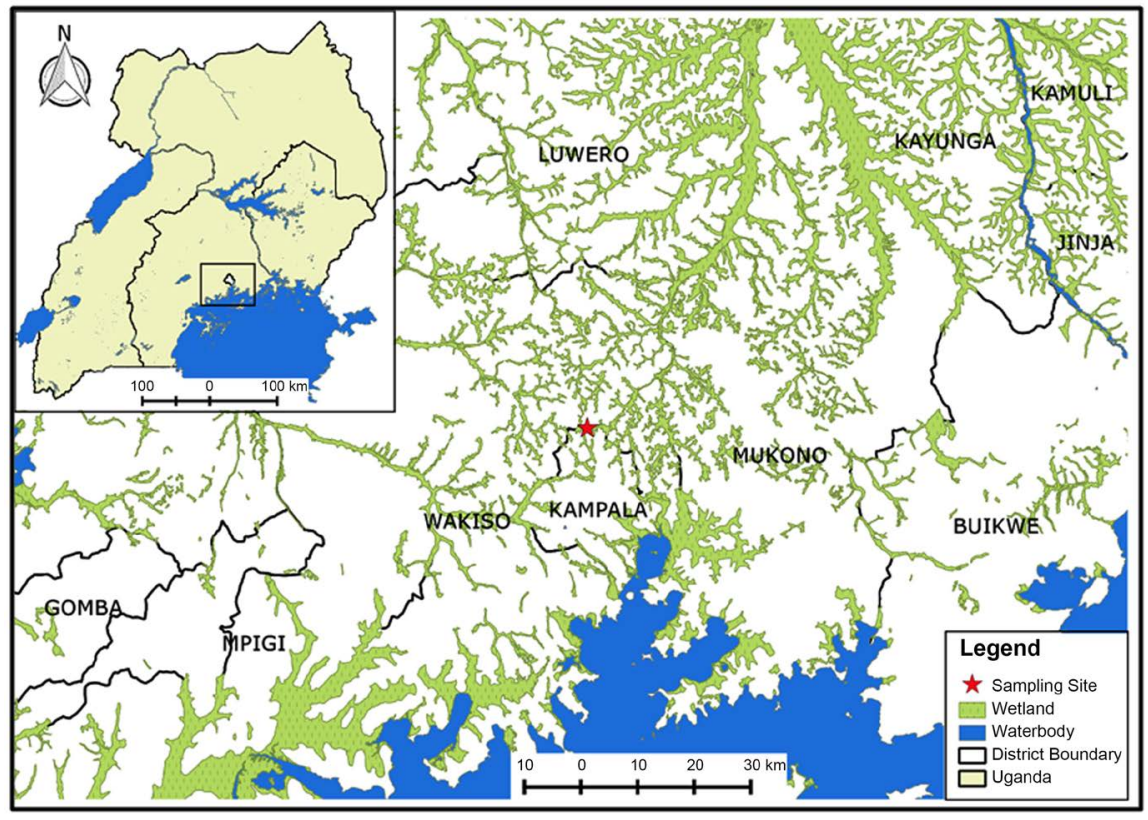

Figure 1. Maps of Uganda showing location of the study site at Kitetika on the boundary of Kampala and Wakiso Districts.

biosolid was collected in a clean polythene bag $(50 \mathrm{~kg})$ from National Water and Sewerage Corporation (NSWC), Bugolobi plant, in Kampala Central Division. This was also spread on a clean polythene sheet, all the non-composted materials were removed, left to dry, sieved and kept for use.

\subsection{Analysis of Materials and Germination Studies}

The CCA soil and composited sewage biosolid were analysed for physico-chemical properties and total levels of AS, $\mathrm{Cr}$ and $\mathrm{Cu}$ using standard methods [11]. The results obtained are given in Table 1 . The composted sewage biosolid was added to the CCA soil at $0,5,10,15,20$ and $25 \% \mathrm{w} / \mathrm{w}$ and each was replicated three times. The composited sewage was mixed well with the CCA soil $(1 \mathrm{Kg})$. The soil mixtures were put in two-litre (2L) plastic containers and these were watered with double distilled water to the soil water holding capacity. The containers were left at room temperature $\left(25^{\circ} \mathrm{C}\right)$ for two weeks for the soil to stabilize but frequently mixed. Loss of nutrients and trace elements out of the buckets was prevented by placing polythene bags under each bucket and any collected leachates were put back in the respective buckets. After two weeks of stabilization, soil samples $(5 \mathrm{~g})$ were scoped from each bucket for physic-chemical characterization using standard methods [11] and the results obtained are given in Table 2.

About 10 seeds of maize (got from a local company FICA Seeds Limited) were soaked in water for 5 hours and six viable ones were sown in each bucket. Watering was done with double distilled water when necessary and hand weeding was used to keep the plants in the buckets free of weeds. Three maize seedlings/plants were plucked out of water-soaked soil at twenty and fourty days after 
Table 1. Physico-chemical parameters of CCA soil and sewage biosolid before use.

\begin{tabular}{ccc}
\hline Soil parameter & CCA soil & Sewage biosolid \\
\hline $\mathrm{pH}$ & 6.77 & 6.64 \\
$\% \mathrm{~N}$ & $0.10 \pm 0.01$ & $0.32 \pm 0.01$ \\
$\% \mathrm{OM}$ & $4.40 \pm 0.08$ & $17.8 \pm 0.26$ \\
$\% \mathrm{OC}$ & $2.50 \pm 0.04$ & $10.3 \pm 0.06$ \\
$\mathrm{P}(\mathrm{mg} / \mathrm{kg})$ & $20.95 \pm 0.17$ & $166.9 \pm 1.04$ \\
$\mathrm{CEC}(\mathrm{meq} / 100 \mathrm{~g})$ & $6.80 \pm 0.32$ & $14.7 \pm 0.11$ \\
$\mathrm{Cr}\left(\mathrm{mg} \cdot \mathrm{kg}^{-1}\right)$ & $365.8 \pm 6.18$ & $35 \pm 1.06$ \\
$\mathrm{Cu}\left(\mathrm{mg} \cdot \mathrm{kg}^{-1}\right)$ & $10972 \pm 14.04$ & $7.2 \pm 0.04$ \\
$\mathrm{As}\left(\mathrm{mg} \cdot \mathrm{kg}^{-1}\right)$ & $28.22 \pm 3.8$ & $\mathrm{nd}$ \\
$\%$ Sand & $74.89 \pm 0.08$ & $51 \pm 0.06$ \\
$\%$ Clay & $19.50 \pm 0.33$ & $15 \pm 0.11$ \\
$\%$ Silt & $8.09 \pm 0.24$ & $34 \pm 0.51$ \\
\hline
\end{tabular}

nd $=$ not detected.

Table 2. Physico-chemical attributes of CCA soil after amendment addition at two weeks before planting.

\begin{tabular}{ccccccc}
\hline \multicolumn{7}{c}{ Amendment (\%) } \\
\hline Parameter & 0 & 5 & 10 & 15 & 20 & 25 \\
\hline $\mathrm{pH}$ & $6.12 \pm 0.11$ & $6.35 \pm 0.02$ & $6.67 \pm 0.08$ & $6.75 \pm 0.08$ & $6.77 \pm 0.003$ & $6.99 \pm 0.18$ \\
$\% \mathrm{~N}$ & $0.11 \pm 0.00$ & $0.197 \pm 0.003$ & $0.27 \pm 0.01$ & $0.32 \pm 0.003$ & $0.44 \pm 0.02$ & $0.50 \pm 0.01$ \\
$\% \mathrm{OM}$ & $4.06 \pm 0.13$ & $9.69 \pm 0.27$ & $10.54 \pm 0.11$ & $14.84 \pm 0.13$ & $15.95 \pm 0.32$ & $16.43 \pm 2.05$ \\
$\% \mathrm{OC}$ & $2.55 \pm 0.01$ & $4.84 \pm 0.01$ & $5.70 \pm 0.01$ & $6.77 \pm 0.02$ & $7.21 \pm 0.01$ & $8.60 \pm 0.03$ \\
$\left.\mathrm{P} \mathrm{(mg.kg}{ }^{-1}\right)$ & $22.99 \pm 0.86$ & $33.08 \pm 2.88$ & $54.13 \pm 3.25$ & $70.82 \pm 2.36$ & $74.27 \pm 1.55$ & $78.15 \pm 1.68$ \\
$\mathrm{CEC}$ & & & & & & \\
$(\mathrm{meq} / 100 \mathrm{~g})$ & $8.34 \pm 0.07$ & $11.53 \pm 0.05$ & $15.70 \pm 0.04$ & $17.81 \pm 0.07$ & $18.84 \pm 0.03$ & $18.96 \pm 0.04$ \\
\hline
\end{tabular}

germination. The shoots were separated from the roots by cutting at $0.5 \mathrm{~cm}$ above the roots. These were washed thoroughly with double distilled water, dried at $70^{\circ} \mathrm{C}$ for three days and pulverized.

\subsection{Determination of Total As, $\mathrm{Cr}$ and $\mathrm{Cu}$ in the Plant Samples}

The pulverized samples were digested separately with a 1:1 mixture of reagent-grade concentrated nitric and perchloric acids. The resulting solutions were filtered into $50 \mathrm{~mL}$ volumetric flasks and topped up to the mark with double distilled water. The concentration of $\mathrm{As}, \mathrm{Cr}$ and $\mathrm{Cu}$ in the digestate were determined by atomic absorption spectrophotometer (AAS, Shumadzu model 6300). The results obtained are given in Table 3.

\subsection{Calculation of Intervention Values}

Intervention values are important because they help indicate whether soil is 
Table 3. Accumulation of As, $\mathrm{Cr}$ and $\mathrm{Cu}$ by roots and shoots at varying amendment rates and number of days.

\begin{tabular}{|c|c|c|c|c|c|c|c|}
\hline & No. of days & 0 & 5 & 10 & 15 & 20 & 25 \\
\hline \multicolumn{8}{|l|}{ Arsenic } \\
\hline \multirow[t]{2}{*}{ Roots } & 20 & $6.69 \pm 1.14$ & $6.66 \pm 1.14$ & $5.58 \pm 0.00$ & $5.58 \pm 0.00$ & $5.56 \pm 0.03$ & $5.54 \pm 0.03$ \\
\hline & 40 & $6.08 \pm 0.01$ & $6.04 \pm 0.01$ & $6.04 \pm 0.00$ & $6.00 \pm 0.01$ & $5.66 \pm 0.05$ & $5.60 \pm 0.19$ \\
\hline \multirow[t]{2}{*}{ Shoots } & 20 & $5.90 \pm 0.13$ & $5.50 \pm 0.01$ & $5.46 \pm 0.01$ & $5.44 \pm 0.02$ & $5.42 \pm 0.01$ & $5.28 \pm 0.03$ \\
\hline & 40 & $5.87 \pm 0.06$ & $5.85 \pm 0.07$ & $5.50 \pm 0.11$ & $5.24 \pm 0.01$ & $5.24 \pm 0.01$ & $5.23 \pm 0.01$ \\
\hline \multicolumn{8}{|c|}{ Chromium } \\
\hline \multirow[t]{2}{*}{ Roots } & 20 & $13.22 \pm 0.03$ & $13.03 \pm 0.07$ & $12.66 \pm 0.10$ & $12.33 \pm 0.06$ & $11.90 \pm 0.02$ & $9.59 \pm 0.02$ \\
\hline & 40 & $10.95 \pm 0.09$ & $10.83 \pm 0.03$ & $10.83 \pm 0.12$ & $10.35 \pm 0.46$ & $10.17 \pm 0.60$ & $9.47 \pm 0.04$ \\
\hline \multirow[t]{2}{*}{ Shoots } & 20 & $10.07 \pm 0.06$ & $9.96 \pm 0.12$ & $9.76 \pm 0.08$ & $9.76 \pm 0.05$ & $9.61 \pm 0.03$ & $9.30 \pm 0.05$ \\
\hline & 40 & $10.07 \pm 0.03$ & $9.98 \pm 0.10$ & $9.98 \pm 0.04$ & $9.73 \pm 0.09$ & $9.69 \pm 0.14$ & $9.52 \pm 0.04$ \\
\hline \multicolumn{8}{|l|}{ Copper } \\
\hline \multirow[t]{2}{*}{ Roots } & 20 & $4.72 \pm 0.15$ & $4.33 \pm 0.32$ & $4.11 \pm 0.19$ & $3.92 \pm 0.08$ & $3.75 \pm 0.05$ & $3.64 \pm 0.12$ \\
\hline & 40 & $4.61 \pm 0.07$ & $4.50 \pm 0.13$ & $4.50 \pm 0.10$ & $4.25 \pm 0.32$ & $3.94 \pm 0.10$ & $3.94 \pm 0.19$ \\
\hline \multirow[t]{2}{*}{ Shoots } & 20 & $4.53 \pm 0.37$ & $3.78 \pm 0.22$ & $3.67 \pm 0.22$ & $3.06 \pm 0.06$ & $2.89 \pm 0.06$ & $2.28 \pm 0.06$ \\
\hline & 40 & $4.53 \pm 0.03$ & $4.44 \pm 0.35$ & $4.25 \pm 0.08$ & $3.86 \pm 0.12$ & $3.58 \pm 0.10$ & $2.94 \pm 0.72$ \\
\hline
\end{tabular}

polluted or not. The equation below was used to calculate the intervention values for the soil used in this study [12]

$$
\mathrm{I}_{\mathrm{c}}=\frac{1^{\mathrm{st}} \times \mathrm{A}+\mathrm{B} \times \% \text { clay }+\mathrm{C} \times \% \mathrm{OM}}{\mathrm{A}+\mathrm{B} \times 25+\mathrm{C} \times 10}
$$

The intervention values applying for the soil being evaluated in $\mathrm{mg} \cdot \mathrm{kg}^{-1}, 1^{\text {st }}=$ intervention value for standard soil $\left[\mathrm{mg} \cdot \mathrm{kg}^{-1}\right.$ for As, $380 \mathrm{mg} \cdot \mathrm{kg}^{-1}$ for $\mathrm{Cr}$, and 190 $\mathrm{mg} \cdot \mathrm{kg}^{-1}$ for $\mathrm{Cu}$ ]; \%clay $=$ measures $\%$ of in the soil being evaluated; $\% \mathrm{OM}=$ Measured \% organic matter in the soil being evaluate; $\mathrm{A}, \mathrm{B}$, and $\mathrm{C}$ are constants which depend on the substances As, $\mathrm{A}=15, \mathrm{~B}=0.4, \mathrm{C}=0.4 ; \mathrm{Cr}, \mathrm{A}=50, \mathrm{~B}=0.4$, $\mathrm{C}=0.0 ; \mathrm{Cu}, \mathrm{A}=15, \mathrm{~B}=0.6, \mathrm{C}=0.6$.

\section{Results and Discussion}

Total concentration of metal $(\mathrm{Cr}, \mathrm{As}$ and $\mathrm{Cu})$ in $\mathrm{CCA}$ soil compared to intervention values.

Figure 2 shows the total metal concentration determined in CCA soil as compared to the intervention values. The intervention values were calculated using the equation as outlined by the Department of Petroleum Resources, Lagos Nigeria [12]. It is clear from both values that CCA soil had high concentration of $\mathrm{Cr}$ and $\mathrm{Cu}$ than the intervention values. Thus, remediation action should be triggered to clean the soil.

\section{Uptake of $\mathrm{Cr}, \mathrm{Cu}$ and As by the Maize Plants}

The application effects of sewage biosolid on the uptake levels of $\mathrm{Cr}$, As and $\mathrm{Cu}$ 


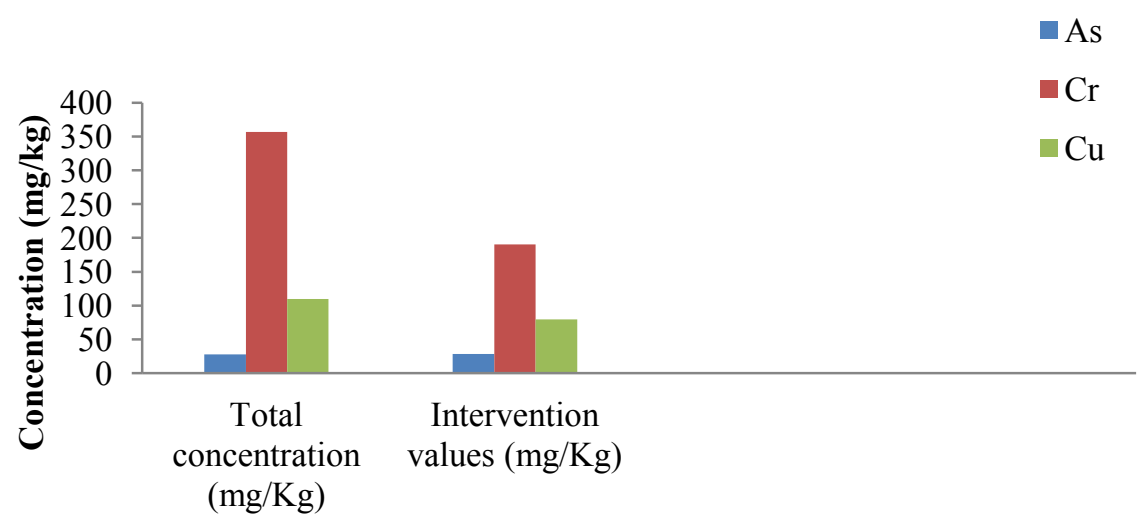

Figure 2. Total concentration of metals $(\mathrm{Cr}, \mathrm{Cu}$, As in CCA contaminated soil as compared to intervention value (DPR, 1991).

from the CCA soil samples by the maize plant are given in Table 3. The results show that addition of sewage biosolid led to a reduction of the uptake levels of the metals by the maize plants. The reduction in metal uptake can be linked to the ability of the sewage biosolid to immobilize or bring to halt the metals in CCA soil. Thus, immobilization process puts the metals into unavailable pools. The constituents of sewage biosolid that would be involved in metal immobilization are cation exchange capacity (CEC), organic matter (OM) and phosphorus (P) amounts (Table 1 and Table 2). The values of $\mathrm{pH}, \mathrm{CEC}, \mathrm{OM}$ and $\mathrm{P}$ of the amended CCA soil increased with the amendment additions. Of the four parameters, $\mathrm{CEC}, \mathrm{OM}$ and $\mathrm{P}$ showed much more marked differences as given in $\mathrm{Ta}$ ble 2 with ranges $11.53 \pm 0.05$ and $18.96 \pm 0.04,9.69 \pm 0.27$ and $16.43 \pm 2.05$ and $33.08 \pm 2.88$ and $78.15 \pm 1.68$ respectively. These could have played a vital role in the retention of the metals by the CCA soil and their uptake by the maize plants.

Dissolved OM is reportedly capable of competing with arsenic for sorption sites and may displace it as As (V) or As (III) from oxides of iron [13]. It has been shown however, that composted organic matter can reduce metal accumulation in vegetables [14] and maize [5] grown on CCA contaminated soil. The movement of metals in soil depends on the chemical forms of the metal. Organic matter can reduce As (V) to more toxic and mobile As (III) which may increase the risk of organisms in the ecosystem. Organic matter can also convert readily $\mathrm{Cr}$ (VI) in presence of $\mathrm{Fe}$ (II) to $\mathrm{Cr}$ (III) or easily co-precipitated with hydrous oxides of iron, thus making $\mathrm{Cr}$ (III) to have low movement and bioavailability in soil [15]. The movement of $\mathrm{Cu}$ in soil increases with lowering the $\mathrm{pH}$ and therefore, its stability depends on $\mathrm{pH}$. Copper has less movement in soil amended with sewage biosolid or compost because it forms stable links with OM, thus decreasing availability [16]. Thus, copper reacts with: 1) organic compounds from sewage biosolid, which control its speciation, movement and bioavailability; 2) organic acids from sewage biosolid, including substances with $\mathrm{O}$-functional groups; and 3) other molecules that form metal complexes, as a result of the properties of organic polyelectrolytes, these complexes reduce the activity of $\mathrm{Cu}$ [17]. Besides, clay, carbonates and phosphorus amounts of soil determine the 
movement of $\mathrm{Cu}$ in soil. The soil with significant amounts of these components, makes the movement of $\mathrm{Cu}$ to be low due to chemical adsorption [18]. Organic matter has a strong affinity $\mathrm{Cu}$ which may result in decreased movement due to strong adsorption on the amended soil particles by high molecular weight organic acids [19]. The phosphorus amount of the sewage biosolid was high (166.9 $\left.\pm 1.04 \mathrm{mg} \cdot \mathrm{kg}^{-1}\right)$. Phosphates are well known for immobilizing metals in soil due to their low solubility (low $\mathrm{K}_{\mathrm{sp}}$ values). This can be through sorption by phosphate and precipitation as metal phosphates [20]. Therefore, amending soil with sewage biosolid with reasonable amount of phosphorus can cause direct sorption through increase surface charge, enhanced anion-induced metal adsorption [5] and precipitation [20]. It would seem from the results that the OM, CEC and P amounts of the sewage biosolid amendment added to CCA soil (Table 2) could account for the immobilization of the metals and render a good explanation for the results obtained in Table 3. The results in Table 3 show metal uptake levels by the maize plant as $\mathrm{Cr}>\mathrm{As}>\mathrm{Cu}$ for both roots and shoots at 20 and 40 days after germination. This was in agreement with the bioavailable pool in the unamended CCA soil.

\section{Conclusion}

The study indicated that the three elements ( $\mathrm{Cr}, \mathrm{Cu}$ and $\mathrm{As}$ ) accumulated mainly in the roots of the maize plant while the shoot contained low levels. The results also indicated that treated and composited sewage biosolid added to contaminated CCA soil was able to immobilize the metals mainly by CEC, P and OM levels through sequestering reactions. Thus, treated and composited sewage biosolid can be used to remediate soils contaminated with heavy metals.

\section{Acknowledgements}

We would like to acknowledge the financial assistance from DAAD and Mbarara University of Science and Technology.

\section{Conflicts of Interest}

The authors declare no conflicts of interest regarding the publication of this paper.

\section{References}

[1] Khodadoust, A.P., Reddy, K.R. and Maturi, K. (2005) Effect of Different Extraction Agents on Metal and Organic Contaminant Removal from a Field Soil. Journal of Hazardous Materials, 117, 15-24. https://doi.org/10.1016/j.jhazmat.2004.05.021

[2] Alloway, B.J. (1995) Soil Process and Behavior of Metals in Soils. Blackie Academic and Professionals, London, 38-57.

[3] Faisal, M. and Hasnain, S. (2004) Bacterial Role in the Reduction of Toxic Cr (VI) in to $\mathrm{Cr}$ (III). Chinese Journal of Biotechnology, 20, 774-778.

[4] Horsfal, M.J. and Spiff, A. (2005) Speciation and Bioavailability of Heavy Metals in Sediment of Diobu River, (Port Harcourt, Nigeria). European Journal of Science, 6 , 
20-36.

[5] Okieimen, F.E., Uwumarongie, I.E.G. and Ikhuoria, E.U. (2011) Effect of Organic Amendments on Metal Accumulation by Maize (Zea mays L.) in Contaminated Soil. International Journal of Agricultural Science, 1, 366-372.

[6] Uwumarongie, E.G. and Okieimen, F.E. (2007) Comparison of Two Sequential Extraction Schemes for Metals in CCA Contaminated Soils. Nigerian Journal of Applied Sciences, 25, 13-21.

[7] Uwumarongie, E.G., Okieimen, F.E. and Uwumarongie, O.H. (2008) Spatial Variation and Speciation of Copper, Chromium and Arsenic in Contaminated Soils. Journal of Chemical Society, Nigeria, 33, 112-121.

[8] Ikhuoria, E.U., Urunmatsoma, S.O.P. and Okieimen, F.E. (2010) Preliminary Investigation of Chemical Fractionation and Heavy Metal Accumulation in Plant Maize (Zea mays) Grown on Chromate Copper Arsenate Contaminated Soil Amended with Poultry Droppings. African Journal of Biotechnology, 9, 2675-2682.

[9] Smith, L.A., Means, J.L. Chen, A. Alleman, B., Chapman, C.C., Tixier, J.S., Brauning, S.E., Gavaskor, A.R. and Royer, M.D. (1995) Remedial Options for Metal-Contaminated Sites. Lewis Publishers, New York.

[10] Wenger, S.K., Gupta, S.K. and Schulin, R. (2008) The Values of Nitrilotriacetate in Chelate-Assisted Phytoremediation. Developments in Soil Science, 32, 679-695. https://doi.org/10.1016/S0166-2481(07)32028-X

[11] Page, A.L., Miller, R.H. and Keeney, D.R., Ed 2 Part II (1982) Methods of Soil Analysis. Madison, WI American Society of Agrononomy, 803.

[12] Department of Petroleum Resources (DPR) (1991) Environmental Guidelines and Standards for the Petroleum Industry in Nigeria (EGASPIN), Lagos, 278-281.

[13] Redman, A.D., Macalady, D.L. and Ahmann, D. (2002) Natural Organic Matter Affects Arsenic Speciation and Sorption onto Hematite. Environmental Science Technolology, 36, 2889-2896. https://doi.org/10.1021/es0112801

[14] Cao, X., Ma, L.Q. and Shillipour, A. (2003) Effect of Compost and Phosphate Amendments on Arsenic Mobility in Soils and Arsenic Uptake by the Hyperaccumulator pterisvittata L. Environment Pollution, 126, 157-167. https://doi.org/10.1016/S0269-7491(03)00208-2

[15] Fendorf, S.E. (1995) Surface Reactions of Chromium in Soils and Waters. Geoderma, 67, 55-71. https://doi.org/10.1016/0016-7061(94)00062-F

[16] Zhu, B. and Alva, A.K. (1993) Differential Adsorption of Trace Metals by Soils as Influenced by Exchangeable Cations and Ionic Strength. Soil Science, 155, 61-66. https://doi.org/10.1097/00010694-199301000-00009

[17] Martinez, C.E. and McBride, M.B. (1999) Dissolved and Labile Concentrations of $\mathrm{Cd}, \mathrm{Cu}, \mathrm{Pb}$ and $\mathrm{Zn}$ in Agd Ferrihydrite-Organic Matter Systems. Environmental Science Technology, 30, 745-750. https://doi.org/10.1021/es980576c

[18] Kabata-Pendias, A. and Pendias, H. (2001) Trace Metals in Soils and Plants. CRC Press, Boca Raton, 4.

[19] Kizilkaya, R. (2004) $\mathrm{Cu}$ and $\mathrm{Zn}$ Accumulation in Earthworm Lumbricusterrestris L. in Sewage Sludge Amended Soil and Fractions of $\mathrm{Cu}$ and $\mathrm{Zn}$ in Casts and Surrounding Soil. Ecological Engineering, 22, 141-151. https://doi.org/10.1016/j.ecoleng.2004.04.002

[20] McBride, M.B. (1989) Reactions Controlling Heavy Metal Solubility in Soils. In: Stewart, B.A., Ed., Advances in Soil Science, Springer-Verlag, New York, 10. 